\title{
IMPROVEMENT OF ORAL HEALTH STATUS IN A GROUP OF STUDENTS WITH VISUAL IMPAIRMENT IN ISTANBUL
}

\section{ABSTRACT}

Objectives: The purpose of this study was to determine the oral health status of a group of students with vision impairment and to compare the changes of oral hygiene after oral health education.

Materials and Methods: Dental examination of 6-19-year-old of 136 students with vision impairment in a Primary School for Individuals with Vision Impairment in Istanbul was performed. The students were divided into 6-9-yearage group (Group I) and 10-19-year-age group (Group II) and in the first visit, they were examined and their findings were recorded according to DMFT (Decayed, Missing, and Filled Teeth), DMFS (Decayed, Missing, and Filled Surfaces) indices of permanent teeth, dft and dfs indices of primary teeth and in the first visit and $3^{\text {rd }}$ follow up period, their Dental Plaque (PI), Calculus (CI) and Oral Hygiene (OHI) Indexes were recorded. They received one-to-one oral health education (OHE). Statistical evaluation was carried out with Wilcoxon and MannWhitney $\mathrm{U}$ tests and $\mathrm{p}<0.05$ was found as statistically significant.

Results: Regarding the pre and post OHE results of periodontal indexes, PI and OHI scores statistically significantly increased after OHE in Group I ( $p<0.05)$. On the other hand, CI results significantly decreased after OHE in Group II $(\mathrm{p}=0.042)$. Comparing post $\mathrm{OHE}$ results of PI and OHI, Group I showed statistically significantly higher scores than Group II $(\mathrm{p}<0.05)$. Comparing the difference values of PI and OHI between pre and post OHE, Group I showed statistically significantly lower scores than Group II $(\mathrm{p}<0.05)$.

Conclusions: Students with vision impairment have a high prevalence of dental caries and poor oral hygiene. We emphasise the importance of providing proper dental education and regular dental visits to them.

Key Words: Oral hygine education, vision impairment, students, dental plaque index
*Kübra Tonguç Altın ${ }^{1}$,

Fatoş Alp ${ }^{2}$,

(iDSerpil Nazlı Aydın²,

(iD) Şule Kavaloğlu Çıldır²,

(D) Nuket Sandalli ${ }^{3}$

ORCID IDs of the authors:

K.T.A.0000-0002-8509-6173

F.A.0000-0001-8637-8263

S.N.A.0000-0002-2514-2481

Ş.K.Ç.0000-0002-6967-7226

N.S. 0000-0002-0381-8583

1 Department of Pediatric Dentistry, Faculty of Dentistry, Yeditepe University, Istanbul, Turkey.

2 Department of Pediatric Dentistry, Faculty of Dentistry, Yeditepe University, Istanbul, Turkey and Pediatric Dentist, Dentarya Dental Clinic, Nicosia, Cyprus.

3 Department of Pediatric Dentistry, Faculty of Dentistry, Yeditepe University, Istanbul, Turkey. and Retired Now.

Received : 24.10 .2018 Accepted $\quad: 12.02 .2019$

How to Cite: Altın KT, Alp F., Aydın SN, Çıldır ŞK, Sandalı N. Improvement of Oral Health Status in a Group of Students with Visual Impairment in Istanbul. Cumhuriyet Dent J 2019;22:1:83-91.

Yeditepe University, Faculty of Dentistry, Department of Pediatric Dentistry, Bagdat Cad. No: 238, 34728, Goztepe, Istanbul, Turkey

Phone: +90 5324073782 Fax: +902163636211 E-mail: kubra.tonguc@yeditepe.edu.tr 


\section{INTRODUCTION}

Oral health has significant biological, psychological, and social consequences due to its effects on aesthetics and communication; furthermore, quality of life is influenced by oral health status. ${ }^{1}$ Good oral health is important for proper mastication, digestion, appearance, speech, and health. ${ }^{2}$ The oral cavity serves an important role in the satisfaction achieved from daily life through functions such as mastication, aesthetics, phonetics, communication, and expression. Oral cavity is an integral part of the body, and dental treatment can affect and be affected by a patient's general physical and mental status. ${ }^{3}$ Oral health is an important aspect of overall health in children and is particularly important for children with special health needs. The oral health of children with visual impairment tends to be compromised as they are at a disadvantage and are often unable to adequately apply plaque control techniques. ${ }^{4}$

Visual impairment is the most frequently occurring disability, followed by speech, hearing, movement, and mental disabilities. ${ }^{5}$ The World Health Organization has estimated the number of individuals with visual impairment (presenting vision) to be 285 million (with $65 \%$ of them being aged $>50$ years). Of them, 246 million have low vision (63\% aged $>50$ years) and 39 million are estimated to be blind ( $82 \%$ aged $>50$ years). ${ }^{6}$ In Turkey, reportedly, almost 130,000 individuals are totally visually impaired; however, individuals afflicted with partial loss of vision increase the number of those suffering from a visual handicap to $>750,000$. In Turkey,>20,000 children are growing up with a visual impairment, and almost 8800 children reach school age every year. ${ }^{7}$

Children with visual impairment face challenges in learning everyday skills, with maintenance of proper oral hygiene being one of them. These children have been found to have a poorer oral hygiene than their sighted peers. ${ }^{8}$ Chang and Shih ${ }^{9}$ have reported that children with visual disabilities have higher levels of oral diseases. Priority is given to teaching these children how to manage their disabilities; consequently, oral hygiene is neglected.
Oral hygiene maintenance is important for preventing periodontal disease and dental caries development. Poor oral hygiene, gingivitis, and periodontal diseases have been reported among the children with visual impairment in studies from India, Iran, and Turkey. ${ }^{4,710,11}$ Mann et al. ${ }^{12}$ have suggested that this is attributable to their inability to visualize plaque on tooth surface, resulting in inadequate plaque removal and subsequent progression of dental caries and inflammatory diseases of the periodontium. Few studies have examined the health information needs of individuals with visual impairment and even fewer have investigated the dental health needs of this group. ${ }^{13}$ Despite the prevalence of visual impairment in Turkey being $0.2 \%^{14}$, little information is available regarding the dental health status and needs of individuals with visual impairment. Some studies have suggested that oral health is compromised in individuals with visual impairment, and these individuals tend to exhibit a higher incidence of dental caries and gingival disease. ${ }^{15-17}$ To determine the comparative oral health care needs of individuals with visual impairment as well as those of sighted people, the oral health status and experiences of such groups with respect to dentistry need to be established. ${ }^{18}$

The aim of current study was to determine the oral health status of a group of students with visual impairment and to compare the changes of oral hygiene after OHE.

\section{MATERIALS AND METHODS}

The present study was registered with the Yeditepe University, Faculty of Dentistry, Institutional Review Board Committee, with the number 266. Signed informed consent forms were obtained from the parents of children, and the study was conducted according to the Helsinki Declaration.

\section{Participants}

A total of 136 students (age range, 6-19 years) with visual impairment with no systemic diseases were examined at the Türkan Sabanc1 Primary School for Children with Vision Impairment connected to the National Education Ministry in 
Istanbul, Turkey. The students were divided into two groups according to their age: a 6-9-year age group (group I) and a 10-19-year age group (group II). The students with visual impairment received one-to-one OHE and motivation with the assistance of dental models and toothbrushes. All students had the ability to brush their teeth by themselves. They were educated by touching and holding toothbrushes with two pediatric dentists. Each of them were taught for twenty minutes. Apart from the tooth brushing education of the students, instructions regarding maintenance of good oral hygiene and horizontal scrub technique of tooth brushing were explained to all their parents.

\section{Inclusion criteria of the study participants:}

1. $100 \%$ bilateral visual impairment (as verified through school medical records)

2. Patient acceptance/cooperation for oral examination

3. Parental compliance

\section{Exclusion criteria of the study participants:}

1. Partial visual impairment/unilateral blindness

2. Concomitant medical conditions

3. Patient cooperation not attained

4. Parental consent not obtained

5. Those without the ability to brush their teeth or whose parents did not participate in the oral hygiene education sessions

\section{Methods}

Intraoral examinations of all students were performed in their schools under artificial illumination of headlamp using a mouth mirror and probe by two calibrated pediatric dentists. Interexaminer reliability was assessed using correlation coefficient (Table 1).

The students were examined on the first visit and then at the 3rd month following it, and pre- and post-OHE findings were recorded. Professional plaque control was not performed for these students in the school conditions. Therefore, following the Mann-Whitney-U tests were used to analyze the results. $\mathrm{p}<0.05$ was considered as significant. first clinical examination, complete plaque removal was performed using toothbrushes by the pediatric dentists

Table 1. Inter-examiner reliability

\begin{tabular}{lcc}
\hline \hline Index & $\begin{array}{c}\text { Intraclass correlation } \\
\text { coefficient }\end{array}$ & $\begin{array}{c}\text { 95\% confidence } \\
\text { interval }\end{array}$ \\
\hline DMFT & 0.841 & $(0.798-0.923)$ \\
\hline DMFS & 0.829 & $(0.833-0.943)$ \\
\hline dft & 0.913 & $(0.897-0.970)$ \\
\hline dfs & 0.867 & $(0.822-0.934)$ \\
\hline PI & 0.906 & $(0.853-0.951)$ \\
\hline CI & 0.897 & $(0.829-0.919)$ \\
\hline OHI & 0.914 & $(0.865-0.953)$ \\
\hline \hline
\end{tabular}

DMFT (Decayed, Missing, and Filled permanent Teeth), DMFS (Decayed, Missing, and Filled permanent teeth Surface), dft (decayed, filled primary teeth), and dfs (decayed, filled primary teeth surface), Plaque Index (PI), Calculus Index (CI) and Oral Hygiene Index $(\mathrm{OHI})$.

Dental caries were diagnosed and recorded according to the criteria of the Decayed, Missing, and Filled (DMF) index. During the intraoral examination, the scores for Decayed, Missing, and Filled permanent Teeth (DMFT); Decayed, Missing, and Filled permanent teeth Surface (DMFS); decayed, filled primary teeth (dft); and decayed, filled primary teeth surface (dfs) were recorded in the first visit. Radiographs were not used for caries detection.

The periodontal health of students was evaluated using the Plaque Index (PI), Calculus Index (CI), and Oral Hygiene Index (OHI) and was recorded at the first visit and at the 3rd month for all students. Oral hygiene was evaluated using the Simplified Oral Hygiene Index and its components, the Plaque Index (PI-S) and the Calculus Index (CI-S). ${ }^{19}$

\section{Statistical analysis}

All the data were analyzed using Number Cruncher Statistical System (NCSS) 2007 Statistical Software (Utah, USA). Wilcoxon and

\section{RESULTS}

Group I comprised $21(51.22 \%)$ males and 20 $(48.78 \%)$ females; Group II comprised 56 (58.95\%) males and $39(41.05 \%)$ females. At the 
first dental examination, the mean values of DMFT, DMFS, dft, and dfs were $2.93 \pm 1.79,3.37$ $\pm 2.93,5.22 \pm 3.5$, and $11.46 \pm 11.47$, respectively, in Group I and 3.64 $\pm 3.02,4.41 \pm 4.37,0.88 \pm 1.58$, and $2.02 \pm 3.92$, respectively, in Group II.

Regarding the pre- and post-OHE periodontal indices, the mean PI scores increased from $0.73 \pm$ 0.54 to $0.91 \pm 0.53$ and the mean $\mathrm{OHI}$ scores increased from $0.75 \pm 0.58$ to $0.91 \pm 0.53$ following OHE in Group I; these increases were significant
( $\mathrm{p}<0.01$ ). Conversely, in Group II, the mean CI scores were significantly decreased from $0.02 \pm$ 0.1 to $0 \pm 0.03$ following $\mathrm{OHE}(\mathrm{p}=0.042)$. When the mean PI scores post OHE were compared between the groups, the scores in Group I were found to be significantly higher than those in Group II ( $\mathrm{p}=0.004)$. Similarly, regarding the mean OHI scores post OHE, the scores in Group I were significantly higher than those in Group II $(\mathrm{p}=0.004)$ (Table 2).

Table 2. Scores of periodontal indices for the two study groups pre and post OHE

\begin{tabular}{|c|c|c|c|c|c|}
\hline Index & Group & & Pre OHE & Post OHE & P-value* \\
\hline \multirow{5}{*}{ PI } & \multirow{2}{*}{ Group I } & Mean \pm SD & $0.73 \pm 0.54$ & $0.91 \pm 0.53$ & \multirow{2}{*}{$0.025 *$} \\
\hline & & Median (IQR) & $0.75(0.28-1.04)$ & $0.6(0.2-1.16)$ & \\
\hline & \multirow{2}{*}{ Group II } & Mean \pm SD & $0.71 \pm 0.62$ & $0.63 \pm 0.57$ & \multirow{2}{*}{0.259} \\
\hline & & Median (IQR) & $1(0.54-1.16)$ & $0.6(0-1)$ & \\
\hline & P-value & & 0.773 & $0.004 *$ & \\
\hline \multirow{5}{*}{ CI } & \multirow{2}{*}{ Group I } & Mean \pm SD & $0.02 \pm 0.12$ & $0 \pm 0$ & \multirow{2}{*}{0.317} \\
\hline & & Median (IQR) & $0(0-0)$ & $0(0-0)$ & \\
\hline & \multirow{2}{*}{ Group II } & Mean \pm SD & $0.02 \pm 0.1$ & $0 \pm 0.03$ & \multirow{2}{*}{$0.042 *$} \\
\hline & & Median (IQR) & $0(0-0)$ & $0(0-0)$ & \\
\hline & P-value & & 0.484 & 0.511 & \\
\hline \multirow{5}{*}{ OHI } & \multirow{2}{*}{ Group I } & Mean \pm SD & $0.75 \pm 0.58$ & $0.91 \pm 0.53$ & \multirow{2}{*}{$0.047^{*}$} \\
\hline & & Median (IQR) & $0.75(0.28-1.04)$ & $0.6(0.2-1.2)$ & \\
\hline & \multirow{2}{*}{ Group II } & $\operatorname{Mean} \pm$ SD & $0.74 \pm 0.64$ & $0.63 \pm 0.58$ & \multirow{2}{*}{0.134} \\
\hline & & Median (IQR) & $1(0.54-1.16)$ & $0.6(0-1)$ & \\
\hline & P-value & & 0.920 & 0.004* & \\
\hline
\end{tabular}

Standart Deviation (SD), Oral Health Education (OHE), Plaque Index (PI), Calculus Index (CI) and Oral Hygiene Index (OHI)

*Statistically significant at $\mathrm{p}<0.05$.

Table 3 shows a comparison of the differences in the periodontal indices pre and post OHE between the two study groups. Regarding the differences in the PI and OHI scores pre and post OHE between the groups, Group I exhibited significantly lower scores than Group II ( $\mathrm{p}=0.01$ and $\mathrm{p}=0.008$, respectively). A higher significant decrease in the $\mathrm{PI}$ and OHI scores was observed in Group II than in Group I post OHE (Table 3).

Table 3. Between-group differences in the pre- and post-OHE periodontal indices

\begin{tabular}{|c|c|c|c|c|}
\hline & \multirow{2}{*}{ Index } & \multicolumn{2}{|c|}{ Difference between pre OHE and post OHE } & \multirow{2}{*}{ P-value* } \\
\hline & & Group I (n:41) & Group II (n:95) & \\
\hline \multirow{2}{*}{ PI } & $\operatorname{Mean} \pm$ SD & $-0.18 \pm 0.49$ & $0.08 \pm 0.76$ & \multirow{2}{*}{$0.01 *$} \\
\hline & Median (IQR) & $-0.25(-0.49-0)$ & $0(-0.3-0.45)$ & \\
\hline \multirow{2}{*}{ CI } & $\operatorname{Mean} \pm$ SD & $0.02 \pm 0.12$ & $0.02 \pm 0.08$ & \multirow{2}{*}{0.484} \\
\hline & Median (IQR) & $0(0-0)$ & $0(0-0)$ & \\
\hline \multirow{2}{*}{ OHI } & Mean \pm SD & $-0.16 \pm 0.52$ & $0.11 \pm 0.79$ & \multirow{2}{*}{$0.008 *$} \\
\hline & Median (IQR) & $-0.25(-0.49-0)$ & $0(-0.3-0.45)$ & \\
\hline
\end{tabular}

Standart Deviation (SD), Oral Health Education (OHE), Plaque Index (PI), Calculus Index (CI) and Oral Hygiene Index (OHI) $*$ Statistically significant at $\mathrm{p}<0.05$.

\section{DISCUSSION}

Oral diseases represent a major health problem 
among individuals with disabilities. ${ }^{20-22}$ Furthermore, the prevalence and severity of oral diseases among this group are higher than those in the healthy population. ${ }^{23}$ Poor periodontal health and oral hygiene have been observed in children with disabilities. ${ }^{24-26}$ These findings may be associated with the low physical abilities of these individuals and consequent difficulties in tooth brushing. Oral health may be affected by the following: limited understanding of the importance of oral health management, difficulties in communicating oral health needs, anticonvulsant medications that affect gum health, and a fear of oral health procedures. ${ }^{21,27-29}$

On comparison of the pre-OHE caries indices between the groups, significantly higher $\mathrm{dft}$ and dfs scores were observed in Group I than in Group II; furthermore, the PI and OHI scores increased post OHE in group I, whereas the CI scores decreased post OHE in Group II. The results indicated that the caries scores were higher in Group I than in Group II. This suggests that students in Group I did not perform tooth brushing properly and that their tooth brushing performance may have been influenced.

On comparing the pre- and post-OHI PI and OHI scores between the groups, group I was found to exhibit significantly lower values than group II. A higher significant decrease in the PI and OHI scores was observed in Group II than in Group I post OHE. Tooth brushing effectiveness is related to psychomotor skills and hand function ability. ${ }^{30}$ A study has reported that chronological age is a reasonable predictor of tooth brushing ability and that the tooth brushing skills of children approach those of adults by the age of 10 years. ${ }^{31}$ The results of the present study suggest that 10-19-year-old students with visual impairment possess the physical ability required for tooth brushing. This is contrary to the findings of Powell ${ }^{32}$ who reported that the oral hygiene level improved with IQ and was not related to chronological age.

In the present study, students with visual impairment were examined on the first visit and then at the 3rd month. The visits had originally been planned in the 1st and 3rd month after the first examination. However, 1 month after the first examination, the students were on a semester break; therefore, the second visit had to be performed in the 3rd month following the first examination. A school-based intervention in children with visual impairment has shown an improvement in oral hygiene shortly following the end of intervention; this study by Costa ${ }^{33}$ demonstrated that the oral health condition 3 months following the end of intervention was poorer than the condition immediately following the end of intervention.

According to Price et al. ${ }^{34}$, when teachers and institutional attendants are included to assist in intervention, a better result can be expected. In the present study, the students with visual impairment received one-to-one OHE and motivation. Their teachers did not attend the education sessions. In future investigations, the involvement of teachers in education and motivation sessions should be planned. According to the literature on preventive OHE, targeting caregivers to establish dental home care could be a successful strategy to improve the oral health of children with special health care needs. ${ }^{35}$ Therefore, we adopted this strategy by including an additional OHE session with parents to improve the oral hygiene of the visually impaired students.

In a previous study in which oral health intervention was performed with students with Down's syndrome, it was reported that a majority of the children were able to perform tooth brushing by themselves. If disabled individuals are motivated and encouraged for self-care, they can manage their own oral hygiene. ${ }^{36}$ Therefore, the students in the present study, comprising children and adolescents, can become capable of managing their own hygiene.

The common methods of tooth brushing in children are the horizontal scrub and modified Bass methods. The horizontal stroke is the most commonly used brushing stroke in children. ${ }^{37,38}$ The advantages of the horizontal scrub method are that it is easy to learn and practice for effective plaque removal. ${ }^{39-41}$ It is important that brushing techniques for patients with disabilities who have fine and gross motor deficiencies are effective and 
simple. Horizontal scrub method is often recommended for such individuals because it is easy and can yield good results. ${ }^{42}$ A study of dental health status in Greek children and teenagers with cerebral palsy, mental retardation, and visual disorders reported that children with vision problems had better oral hygiene than those with other disabilities because the former are able to better comprehend the oral hygiene instructions and possess superior kinetic skills. ${ }^{43}$ The horizontal scrub technique was explained to the students and their parents in the present study.

The present study was performed at a public school. Similarly, Bekiroglu et al. ${ }^{10}$ conducted their study at a public school (Türkan Sabanc1 Primary School for Children with Vision Impairment); in their study, it was found that only $26.40 \%$ of the children were caries-free. In contrast, examinations by Oredugba and Akindayomi ${ }^{44}$ and Desai et al. ${ }^{45}$ were performed in private schools; in their studies, $66.7 \%$ and $53 \%$ of the subjects were found to be caries-free. The educational level and socioeconomic status of students' parents are higher in most private schools than in public schools. Therefore, children in private schools tend to be more aware of oral health care than those in public schools. Looking at these studies, the present study may be extended by including the examination of individuals with visual impairment in private schools.

Visual impairment affects the oral health through physical, social, or informational barriers associated with impairment, attendant medical condition (and associated medical disorders), and a lack of customized information. ${ }^{46}$ The provision of good oral instructions and tactile devices to improve the tooth brushing skills of children with visual impairment is considered the most important aspect of oral hygiene education. ${ }^{47,48}$ Children with visual impairment depend more on sound, speech, and touch to orient themselves to a particular situation. ${ }^{49}$ Therefore, modification of OHE is required when teaching these groups of children. Shetty and Hegde ${ }^{50}$ have evaluated the Gingival Index (GI) and PI scores of children with visual impairment at the beginning of their study and following OHE. They imparted OHE with the assistance of specially designed models, and tooth brushing was taught with specially formulated music-aided instructions in a song format. They found a significant drop in PI and GI scores from the pre- to post-OHE levels.

Education and motivation of the parents of children with visual impairment is vital toward improving and maintaining oral health and the overall general health of these children. ${ }^{51}$ Bhandary and Shetty ${ }^{8}$ have assessed the basic information on the oral health care knowledge of parents/care providers of children with visual impairment through a simple pre-structured questionnaire and have reported that there is a general lack of awareness among the care providers of these children regarding dental diseases and their prevention; furthermore, they have found the importance of oral hygiene among these care providers to be low. In a future investigation, we plan to obtain information on oral health care from parents of children with visual impairment through a questionnaire and plan to provide an OHE conference to parents, teachers, and care providers regarding oral hygiene, tooth brushing, and dietary guidance for children with visual impairment to enhance their health care.

\section{CONCLUSIONS}

A high caries prevalence demonstrates extensive unmet needs for dental treatment in students with visual impairment. It is an alarming situation that suggests the requirement of immediate dental treatment prior to a prevention-based intervention program for this group of children. The dental treatment costs were met by the Institution of Social Security. Therefore, dentists play a key role in not only diagnosing the oral health conditions of these children but also treating them and maintaining their oral health to contribute to their general well-being.

In the present study, the periodontal health of the students with visual impairment improved at the 3rd month follow-up. These results suggest that providing OHE interventions that include supervised tooth brushing during the school 
classes can be a valuable approach for improving oral hygiene status. Further studies are necessary to assess the long-term sustainability of such educational interventions.

\section{ACKNOWLEDGEMENTS}

We would like to thank students and parents of Türkan Sabanc1 Primary School for Children with Vision Impairment and Ms Rana Konyalioglu for statistical expertise.

\section{CONFLICTS OF INTEREST}

The authors declare that there are no conflicts of interest regarding the publication of this paper.

\section{İstanbul İlindeki Bir Grup Görme Engelli Öğrencinin Ăğı Diş Sağlı̆̆ındaki Değişiklikler}

\section{$\ddot{O} Z$}

Amaç: Bu çalışmanın amacl, bir grup görme engelli öğrencinin ăglz ve diş să̆lı̆̆ durumlarının belirlenmesi ve ăğz-diş sağlı̆̆ ĕgitimlerinden sonra ă̆ız hijyenindeki değişikliklerin değerlendirilmesidir. Gereç ve Yöntemler: Yaşları 6-19 arasında olan, T.C. MEB Türkan Sabancı Görme Engelliler Illköğretim Okulu'nda okuyan 136 görme engelli ögrencinin ă̆ıdiş muayeneleri yapıldı. Öğrenciler yaşlarına göre 6-9 yaş grubu (Group I) ve 10-19 yaş grubu (Group II) şeklinde ikiye ayrıld. Muayene çıplak gözle ve aynasond yardımı ile gün ışığında gerçekleştirildi. Muayene sırasında DMFT, DMFS, dft, dfs, plak (PI), diştaşı (DI) ve oral hijyen indeksleri (OHI) kaydedilen tüm öğrencilere, birebir diş firçalama ĕgitimi verildi (OHE). 3 ay sonra aynı çocukların ă̆ız-diş să̆lı̆̆ gelişimlerinin izlenebilmesi amacı ile ikinci kez muayeneleri yapıld. Istatistiksel değerlendirmede Wilcoxon ve Mann Whitney $U$ testleri kullanıld ve sonuçlar $p<0,05$ anlaml kabul edildi. Bulgular: OHE'den sonra Group I'in PI ve OHI değerlerinde artış olduğu görüldü ( $p<0,05)$. Diğer bir taraftan, OHE'den sonra Group II'nin DI değerlerinde azalma gözlemlendi $(p=0,042)$. OHE sonrası PI ve OHI skorları karşılaştırıldı̆̆ında, Group I'deki değerlerin Group II'den istatistiksel olarak anlaml derecede yüksek bulundu (p<0,05). Group I'in eğitim öncesisonrası, PI ve OHI değerleri arasındaki farkın, Group II'deki değerler arasındaki farktan istatistiksel olarak anlamll derecede düşük bulundu (p<0,05). Sonuçlar: Görme engelli ögrencilerin diş çürüğü sıklı̆̆ının fazla

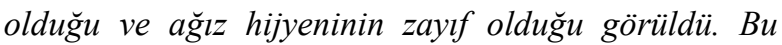
bireylerin düzenli aralıklarla ăglz-diş sağlı̆̆ kontrollerinin yapılmasının ve uygun ĕgitimlerin verilmesinin çok önemli olduğunu düşünmekteyiz. Anahtar Kelimeler: Ăglz hijyeni ĕgitimi, görme engelli, ögrenciler, dental plak indeksi.

\section{REFERENCES}

1. Gabre P, Martinsson $T$, Gahnberg L. Incidence and reasons for tooth mortality among mentally retarded adults during a 10-year period. Acta Odontol Scand 1999;57:55-61.

2. Fiske J, Davis DM, Frances C, Gelbier S. The emotion- al effects of tooth loss in edentulous people. Br Dent J 1998;184:90-93.

3. Stefel DJ, Edmond L. The role of rehabilitation dentistry. Good oral health and hygiene for people with disability contributes to rehabilitation. American rehabilitation 1990.

4. Shetty V, Hegde AM, Bhandary S, Rai K. Oral health status of the visually impaired children--a south Indian study. J Clin Pediatr Dent 2010;34:213-216.

5. Dinesh Rao B, Arnitha Hegde M, Munshi AK. Caries prevalence amongst handicapped children of South Canara, India. J Indian Soc Pedod Prev Dent 2001;4:67-73.

6. Silvio P. Mariot et al. Global data on visual impairment in the year 2010. Bull World Health Organ, 2012.

7. Yalcinkaya SE, Atalay T. Improvement of oral health knowledge in a group of visually impaired students. Oral Health Prev Dent 2006;4:243-253.

8. Bhandary S, Shetty V, Hegde AM, Rai K. Knowledge of care providers regarding the oral health care of visually impaired children. J Clin Pediatr Dent 2013;37:385-389.

9. Chang CS, Shih Y. Teaching oral hygiene skills to elementary students with visual impairments. J Vis Impair Blindness 2005;99:26-39.

10. Bekiroglu N, Acar N, Kargul B: Caries experience and oral hygiene status of a group of visually impaired children in Istanbul, Turkey. Oral Health Prev Dent 2012;10:75-81.

11. Ahmad MS, Jindal MK, Khan S, H: HS: Oral health knowledge, practice, oral hygiene status and dental caries prevalence among visually impaired students in residential institute of Aligarh. J Dent Oral Hyg 2009; 1:022-026.

12. Mann J, Joseph SW, Lavie G, Carlin Y, Garfunkel AA: Periodontal treatment needs and oral hygiene for institutionalized individuals with handicapping conditions. Spec Care Dentist 1984;4:173-176.

13. Beverley CA, Bath PA, Booth A. Health information needs of visually impaired people: a systematic review of the literature. Health Soc Care Commun 2004;43:1-24.

14. Negrel AD, Minassian DC, Sayek F. Blindness and low vision in South East Turkey. Ophthal Epidemiol 
1996;3:127-134.

15. Chowdary PB, Uloopi KS, Vinay C, Rao VV, Rayala C. Impact of verbal, Braille text, and tactile oral hygiene awareness instructions on oral health status of visually impaired children. J Indian Soc Pedod Prev Dent 2016;34:43-47.

16. Sandeep V, Vinay C, Madhuri V, Rao VV, Uloopi $\mathrm{KS}$, Sekhar RC. Impact of visual instruction on oral hygiene status of children with hearing impairment. J Indian Soc Pedod Prev Dent 2014;32:39-43.

17. Nowak AJ. Dental care for the handicapped patient - Past, present, future. In: $1^{\text {st }}$ ed. Dentistry for the Handicapped Patient. St. Louis, MO:C V Mosby, 1976:3-20.

18. Jain A, Gupta J, Aggarwal V, Goyal C. To evaluate the comparative status of oral health practices, oral hygiene and periodontal status amongst visually impaired and sighted students. Spec Care Dentist 2013;33:78-84.

19. Greene JC, Vermillion JR. The simplified oral hygiene index. J Am Dent Assoc 1964;68:7-13.

20. Scott A. March L. Stokes ML. A survey of oral health in a population of adults with developmental disabilities: Comparison with a national oral health survey of the general population. Aust Dent J 1998;43:257-261.

21. Faulks D. Hennequin M. Evaluation of a long-term oral health program by carers of children and adults with intellectual disabilities. Spec Care Dentist 2000;20:119-208.

22. Jurek GH. Reid WH. Oral health of institutionalized individuals with mental retardation. Am J Ment Retard 1994;98:656-660.

23. Beange H. Caring for a vulnerable population: Who will take responsibility for those getting a raw deal from the health care system? Med J Aust 1996;164:159-160.

24. Gizani S. Declerck D. Vinkier F. Martens L. Marks L. Goffin G. Oral health condition of 12-year-old handicapped children in Flanders (Belgium) Community Dent Oral Epidemiol 1997;25:352-357.

25. Al-Qahtani Z. Wyne AH. Caries experience and oral hygiene status of blind, deaf and mentally retarded female children in Riyadh, Saudi Arabia. Odontostomatol Trop 2004;27:37-40.

26. VanHoutem CM. de Jongh A. Broers DL. Van der Schoof M. Resida GH. Post- academic specialties 9. Dental care of disabled children living at home. Ned TijdschrTandheelkd 2007;114:129-133.

27. Lindemann R. Zaschel-Grob D. Opp S. Lewis MA. Lewis C. Oral health status of adults from a California regional center for developmental disabilities. Spec Care Dentist 2001;21:9-14.

28. Marshall RI. Bartold PM. A clinical review of druginduced gingival overgrowths. Aust Dent J 1999;44:219-232.

29. Gordon SM. Dionne RA. Snyder J. Dental fear and anxiety as a barrier to accessing oral health care among patients with special health care needs. Spec Care
Dentist 1998;18:88-92.

30. Hartwig AD, Stüermer VM, da Silva-Júnior IF, Schardosim LR, Azevedo MS. Effectiveness of an oral health educational intervention for individuals with special health care needs from a southern Brazilian city. Spec Care Dentist 2017;37:246-252.

31. Unkel JH, Fenton SJ, Hobbs G, Frere CL. Toothbrushing ability is related to age in children. ASDC J Dent Child 1995;62:346-348.

32. Powell EA. A quantitative assessment of the oral hygiene of mentally retarded residents in a state institution. J Public Health Dent 1973;33:27-34.

33. Costa FS, Neves LB, Bonow MLM, Azevedo MS, Schardosim LR. Effectiveness of an educational strategy on oral health of visually impaired children. RFO 2012;17:12-17.

34. Price JH. Dental health education for the mentally and physically handicapped. J School Health 1978;48:171-174.

35. Huebner CE, Chi DL, Masterson E, Milgrom P. Preventive dental health care experiences of preschoolage children with special health care needs. Spec Care Dentist 2015;35:68-77.

36. Shyama M, Al-Mutawa SA, Honkala S, Honkala E. Supervised toothbrushing and oral health education program in Kuwait for children and young adults with Down syndrome. Spec Care Dentist 2003;23:94-99.

37. Sundell SO, Klein H. Toothbrushing behavior in children: a study of pressure and stroke frequency. Pediatr Dent 1982;4:225-228.

38. RuggGunn AJ, Macgregor IDM. A survey of toothbrushing behaviour in children and young adults. J Periodontal Res 1978;13:382-389.

39. McClure DB. A comparison of toothbrushing technics for the preschool child. J Dent Child 1966;33:205-210.

40. Robinson E. A comparison evaluation of the scrub and bass methods of toothbrushing with flossing as an adjunct (In fifth and sixth graders). Am J Public Health 1976;66:1078-1081.

41. Anaise JZ. The toothbrush in plaque removal. J Dent Child 1975;42:186-189.

42. Weddell JA, Sanders BJ, Jones JE. Dental problems of children with disabilities. In: Mcdonald RE, Avery DR, Dean JA (eds). Dentistry for the Child and Adolescent, 8th edn. St Louis: Mosby, 2004; 572.

43. Mitsea AG, Karidis AG, Bakoyianni CD. Oral health status in Greek children and teenagers with disabilities. J Clin Pediatr Dent 2001;26:111-118.

44. Oredugba FA, Akindayomi Y. Oral health status and treat- ment needs of children and young adults attending a day centre for individuals with special health care needs. BMC Oral Health 2008;8:30.

45. Desai M, Messe LB, Calache H. A study of the dental treat- ment needs of children with disabilities in Melbourne, Australia. Aust Dent J 2000;46:41-50.

46. Lebowitz EJ. An introduction to dentistry for the blind. Dent Clin North Am 1974;18:651-659.

47. Mahoney EK, Kumar N, Porter SR. Effect of visual impairment upon oral health care: a review. Br Dent J 2008;204:63-67. 
48. O'Donnell D, Crosswaite MA. Dental health education for the visually impaired child. J R Soc Health 1990;110:60-61.

49. Morsey SL. Communicating with and treating the blind child. Dent Hyg 1980;54:288-290.

50. Shetty V, Hegde AM, Varghese E, Shetty V. A novel music based toothbrushing system for blind children. J Clin Pediatr Dent 2013;37:251-255.

51. Fort Chang and Shih Chang and Shih Chang and Shih ester DJ, Wagner ML, Fleming. In: Henry Kimpton Publishers. J Pediatric Dental Medicine. Lea and Febiger 1981. 